\title{
Flipped Classroom Learning Model and Its Availability in Turkish Education $^{1}$
}

\author{
Erhan Akın \\ Correspondence: Assist. Prof. Dr., Erhan Akın, Siirt University, Faculty of Education, Turkish Education Department \\ Siirt, Turkey. \\ Received: August 22, 2016 \\ doi:10.11114/jets.v4i11.1825 \\ Accepted: September 22, $2016 \quad$ Online Published: September 29, 2016 \\ URL: http://dx.doi.org/10.11114/jets.v4i11.1825
}

\begin{abstract}
Technological developments, which entered into educational environment, led up new developments on behalf of rescuing education from locking in certain environments by expanding its domain. One of these developments, subject of our study, is the learning model called Flipped Classroom. In this model, students are able to continue their education without depending on their teachers and classrooms and breaking off from them. This model may be more effective particularly for the courses aimed at teaching skills. Turkish education is a course thought for basic language skills. Basic language skills require practice rather than theory. Learning and teaching of a skill can be provided as a result of effective use of the practice environment. It is expected to be learned at the highest level by a model which is called Flipped Classroom and settled to the literature as "Flipped Classroom". For this purpose, the field related to Flipped Classroom model was browsed at first, and then theoretical framework of the study was created by reaching relevant sources and the emphasis was laid on the availability of this model in Turkish education. Recommendations related to field of the study were made.
\end{abstract}

Keywords: flipped classroom learning model, Turkish education, availability

\section{Introduction}

\subsection{Education and Technology}

On behalf of keeping up with technological developments; changes and transformations made in many fields such as art, trade, politics, and tourism can also be seen in the education field. Education covers and directs all these fields. It meets the need of qualified labor force for these fields. Education field, which has utmost importance, cannot be considered as deprived of technology. Because, if these opportunities are not used in education, any part of all other fields can be missing. Education cannot be separated from technological developments not only for the above-mentioned fields but also for the daily needs of individuals. Almost all communication and enlightenment ways of people used in daily life are provided by technological tools. If individuals can meet with these tools very often, then trainings should be given to them related to the usage of these tools more efficiently and effectively, these tools should be used for their trainings.

Technological tools have become the center of our daily lives. They continue to make rapid progress. Rate and area of utilization of tools such as computer, internet, telephone etc., which are used in order to facilitate the lives of individuals, continue to increase day by day (Bayhan, Olgun and Yelland, 2002). This area of utilization expands gradually and technology takes part in all fields of life. Especially new generation is born and grows with technology. Indeed, Prensky (2001) uses the concept of digital citizens for new generation in his study. Digital citizens use technological tools in many fields ranging from education to entertainment, from trade to tourism. Technological tools are indispensable for this generation. This condition shows itself in FATIH project, which is put into effect by the Ministry of Education. The ways of using technology in a more purposeful and efficient way are being pursued instead of protecting new generation from technology.

Thanks to FATIH project, it is shown that technological developments can be used for students in educational environment as well. Technology began to take its place in educational environment with this project. In classrooms,

\footnotetext{
${ }^{1}$ This study has been prepared with reference to notice called "An Analyze on Flipped Classroom Learning Model" presented in XVIII. World Congress with "preparing today's education for the future" by World Education Sciences Association (AMSE-AMCE-WAER) in Eskisehir Anadolu University between 30 May - 2 June 2016.
} 
students use tools such as smart boards, tablets etc. for learning, and they continue to use them at home for cases like homework, practice etc. Odabaşı and Namlu (2008) stated in their study that audio-visual tools, computer technologies provide great contributions to teachers and students in their studies as a result of the development of technology. Information related to life show improvement day by day in communication and information era. It is unlikely to keep up with this speed through traditional ways. As a result of this, educational environments which are appropriate for all stakeholders of the education, who don't receive information as is, question, use technological tools effectively, improve themselves to have critical thinking skills, should be established. One of the significant ways to create such educational environments is educational environments, in which technological tools are included to work.

It is thought that including technological tools into work provides benefit to all stakeholders of education. This condition is also seen in the studies carried out in this field (Davis\& Shade, 1994; Odabaş1, 2010; Tezci and Perkmen, 2013; Spector, 2013). Technological developments, which entered into educational environment, led up new developments on behalf of rescuing education from locking in certain environments by expanding its domain. One of these developments, subject of our study, is learning model called Flipped Classroom.

\subsection{Flipped Classroom Learning Model}

In this model, students are able to continue their education without depending on their teachers and classrooms and breaking off from them. The requirement of the student-oriented education system as a principle of constructivist education system can be met by this training and students can commune with education at all hours of the day wherever they want by this system. In this way, student will have prior knowledge about the subject before he/she comes to the classroom. Students can learn theoretical information before they come to classroom and they can spend their time for practice in the classroom. Learning or teaching of a subject can be provided by effective use of field of application. It is expected to be learned at the highest level by a model which is called as Flipped Classroom and settled to the literature as "Flipped Classroom".

Flipped classroom learning model is a learning model, which is being discussed for a long time abroad and given importance in our country in recent years. Radical changes are being realized in the education environment with this model. Now students learn theoretical information at home and have courses focused on practice in the classroom. The allocation of time to practice by students may be a great opportunity on behalf of learning environment (Tucker, 2012) and more qualified, effective classroom environment can be created with this model (Bergman and Sams, 2012; Fautch, 2015). Flipped classroom can be defined as a model, which gives students the opportunity to reach and use information individually, while recommending them to do the things they will do in the classroom at home and do the things they will do at home in the classroom through solving their own problems by themselves (Verleger\& Bishop, 2013). Thus, student can apply for learning methods without depending on the classroom environment. The exact opposite situation of traditional teaching ways is experienced. The course is not thought by teacher in the classroom by straight speech or other methods. Teacher supplies information related to course to his/her student before coming to the classroom and students learn this information at home first and then come to the classroom with the knowledge about the subject. Therefore, thanks to students coming to the classroom with the prior knowledge about the subject, more time remains for group works and practices in the classroom.

It is stated in some studies made abroad in body of literature that students having education with flipped education model are more active and open for improvements compared to students having education with traditional method, while successes of students increase with this model, more subjects can be taught in courses, teachers can spend most of their time for practices and activities, students have positive attitudes towards flipped classroom learning model and their motivation levels are always at the top level (Gannod, Burge \&Helmick, 2008; Strayer, 2012; Johnson and Renner, 2012; Tune, Sturek and Basile, 2013; Mason, Shuman and Cook, 2013; Davies, Dean and Ball, 2013; McGivney-Burelle and Xue, 2013; Touchton, 2015). It has been emphasized that flipped learning model is a great innovation, but its field of utilization hasn't been expanded yet as desired, especially universities didn't do in-depth practices and theoretical studies at desired level (Roach, 2014; Bergmann and Sams, 2012; Mattis, 2014). In some studies,it is stated that flipped classroom learning model doesn't increase success but this model is welcomed warmly by students (Johnson and Renner, 2012; Missildine, Fountain, Summers and Gosselin, 2013; Findlay and Mombourquette, 2013; Love, Hodge, Grandgenett and Swift, 2014).

Some studies conducted about Flipped Classroom model in our country can be listed as follows:

In their study called as "An Example for the Use of Technology As a Material in Language Teaching: Flipped Classroom", Temizyürek and Ünlü (2015) state that all education stakeholders needed to renew themselves in line with the developments of educational technology. One of the important fields of this innovation was in language teaching. Temizyürek and Ünlü say that language teachers benefit from these developments in their classes and emphasize that if teachers don't synchronize their teaching methods with learning methods of the new generation, learning process will 
not be successful. Then they emphasize that "Flipped Classroom" learning model is one of the models outstanding in the West and draw attention that students can monitor theoretical information outside the class where they want unlike traditional methods and can make activities given to them as homework with the guidance of their teachers in classrooms.

In his "A Case Study About the Implementation of Flipped Classroom Model in Schools (2015)" titled thesis, Gençer examined the use and applicability of Flipped Classroom educational model, which is known as the displacement of homework and in-class activities and stated as activating the student during the learning process, and made a case study in a school. As a result of this study, the researcher stated that even though the workload of teachers increase in cases as making research related to learning the model, preparation and presentation of the course materials within the scope of the implementation of flipped classroom model; yet students play a more active role in the learning process, take their own individual learning responsibilities and spend more time for in-class activities with the transformation of homework process which they find boring. As a result of this, he stated that this model is accepted by students and makes significant contribution to the success of students.

In their study prepared from the doctoral thesis called "A New Approach in Higher Education: Opinions of the Students for Flipped Classroom Method", Turan and Göktaş (2015) tried to determine the opinions of students about flipped classroom method. As a result of the study, it is stated that students have quite positive opinions regarding Flipped Classroom method. Afterwards, they drew attention to positive opinions of the students as a result of that flipped classroom method increases the persistency of learning, it facilitates learning, it is an enjoyable and flexible method. Another point to be taken into consideration are the disadvantages of flipped classroom method as there is lack of technical tools, it takes lots of time, videos are required to be watched prior to courses.

In their "Achievability of Flipped Classroom Model in Mobil Learning Environments" titled study, Torun and Dargut (2015) remarked the crowded number of students in the current environment and insufficient course time to perform the learning activities. They also emphasized the importance of Flipped Classroom model that will meet the expectations of the students. By this model, students state that they realize their information process through non-class activities. In class, they express an opinion on the subject of strengthening learning and sparing more time for practices. They emphasize that in this model they don't adhere to any place in non-class activities as seen in mobile learning.

In their "Course at Home, Homework at School" titled study, Demiralay and Karataş (2014) stated that flipped or inverted classroom, Course at Home, Homework at School(flipped classroom) model, which prevails often in foreign literature, is a learning model trying to stand out in our country recently. They argued about the place of Course at Home; Homework at School model in blended learning environments and examined the development of the model and the contribution of the model to learning environments in their study.

Based on the findings obtained as a result of the research made by Demiralay (2014) under the name of "Analysis of Course at Home, Homework at School Model Adoption Process within the Framework of Diffusion of Innovation", he emphasized that Course at Home, Homework at School Model is associated with education with tablet; there isn't any change agent in the diffusion process; there are different decision processes in teacher-teacher, student-teacher, administrator-teacher, parent-teacher systems; need variable is effective on the decision of model use, and age groups, grade levels, exam preparation status of students are effective on the decision of non-use. The common sense attributed to Course at Home, Homework at School Model is that; it is useful and observable learning model for students; for teachers it is a mixed flexible learning model, requiring the use of tablets, appropriate depending on experience, applicable in several course times or throughout the whole course, requiring perception of institutional support.

In his "Implementation of Flipped Learning Model in Individual Instrument Violin" titled study, Sever (2014) says that it is a model taking students to the center in-class practices. Then, he put the flipped classroom learning into effect in the field of violin education. The researcher got his student to watch a video, which was prepared for the student who couldn't come to class due to health problems, and tried to teach his course by this way. The researcher took and analyzed the opinion of the student for this implementation after the course. As a result of the analysis, the implementation of flipped classroom learning method in individual violin courses saved time for the stakeholders of the education and made teaching more effective and efficient. The student felt himself more comfortable and was motivated better to improve his skills in this direction by this model.

In his "Evaluation of Flipped Classroom Implementation in English Teaching" titled thesis, Boyraz (2014) analyzed the effect of the new Flipped Classroom teaching method in English teaching on academic success and retention. He concluded that the experimental group, who were taught by flipped classroom method, was at a greater level in terms of academic success than the control group, who were taught by traditional method.

In his "Evaluation of Effects of Flipped Classroom Learning Model on Middle-School Students" titled study, Kapçık (2014) created two groups consisting of 36 students from $7^{\text {th }}$ grade as control and experimental groups including 18 
students within the scope of Scientific and Technological Research Council of Turkey (TUBITAK) project. He taught "Population" subject of Social Sciences to control group by normal teaching and to experimental group by flipped classroom model. Videos prepared in accordance with the flipped classroom model were requested to be watched by students wherever and whenever they want. As a result of the study, an increase was observed in the success of experimental group which was taught by using flipped classroom method.

When reviewing body of the literature, it seen that traditional educational methods are compared with flipped classroom learning model throughout the studies. As it can be understood from the comparison of these two models; the situation in the education system reverses. Traditional model, in which information is transferred by teacher, gives its place to Flipped Classroom learning model, in which information is tried to be learnt by students, and this information is reinforced with activities in classrooms. Everything has changed by this model. Serçemeli (2015) transfers this situation in the study from Zownorenga as follows: Flipped classroom approach came up with the idea of giving education traditionally continuing in the classroom by being monitored at home. Then, it is intended to absorb in advance given information by different methods by the teacher during course time in class. It is achieved with the help of video records, which give possibility to prior-watch.Thus, teacher gains the ability to deal with students one to one in-class time. So, time spent in the classroom can be evaluated in a more effective manner (Zownorenga, 2013).

When body of literature is reviewed, the comparison of flipped classroom learning model with traditional model can be seen as follows:

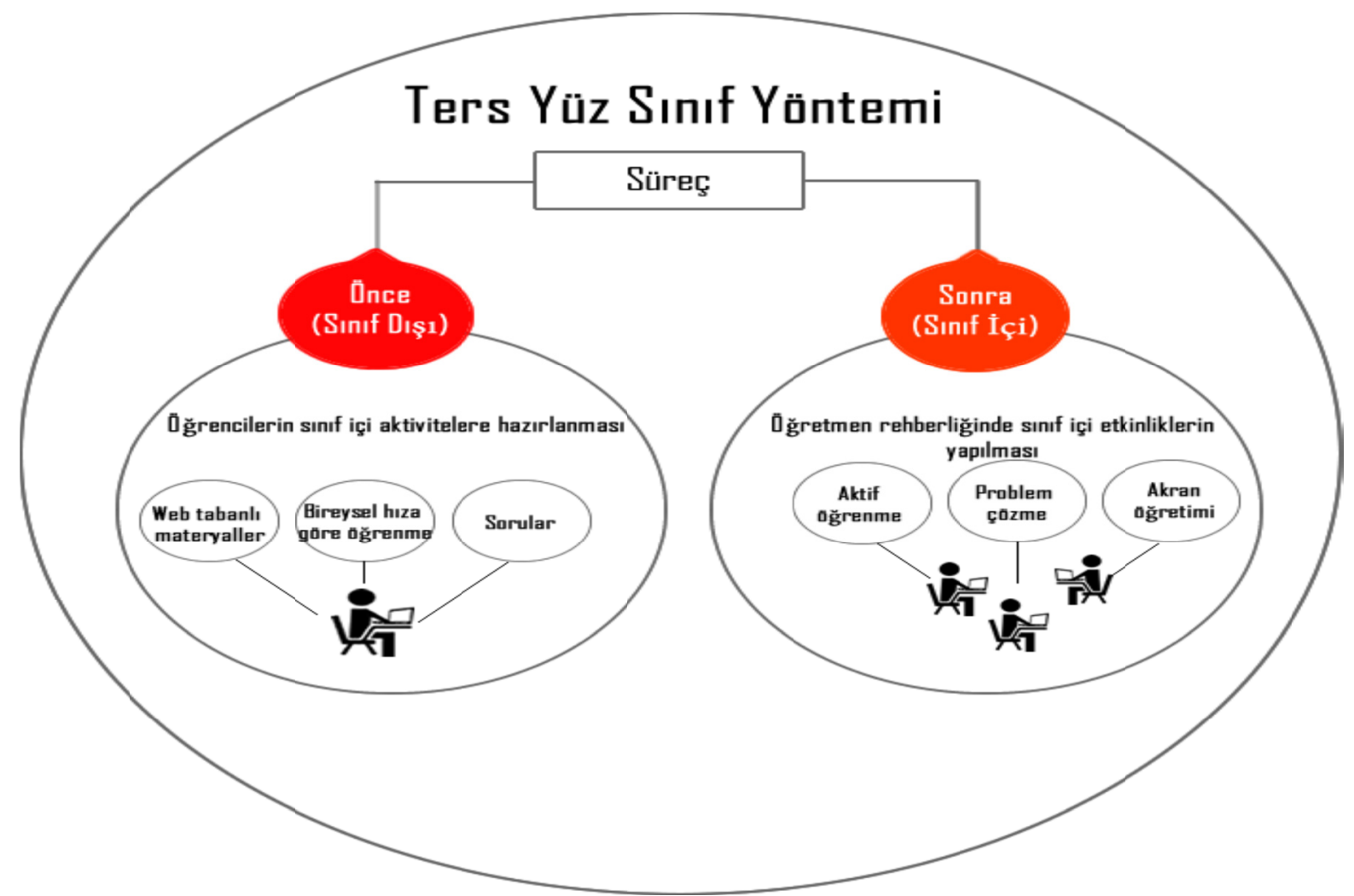

Figure 1. Flipped Classroom Learning Model with Traditional Education Models (Turan, 2015)

\section{Availability of Flipped Classroom Learning Model in Turkish Education}

Flipped Classroom Learning Model may be more effective particularly for the courses aimed at teaching skills. Turkish education is a course thought for basic language skills. Basic language skills require practice rather than theory. Learning and teaching of a skill can be provided as a result of the effective use of the practice environment. It is expected to be learned at the highest level by a model, which is called Flipped Classroom and settled to the literature as "Flipped Classroom".

As basic language skills are in touch with each other and all require application, it is thought that the availability of flipped classroom learning model in this course is possible. It may not be enough for the teaching of language skills to give lesson only about language skills or teach through some activities put into practice mostly by the teacher. The teacher may transmit the videos and presentations that have been prearranged or seem applicable to the students using 
flipped classroom learning model. The teacher may prepare some questions about the knowledge that is prearranged for the students gained by them after the presentation. Students may have theoretical knowledge about the subject before attending to the class based on these presentations and talk about the questions that are asked to show their knowledge about the presentations. The teacher may use the time saved for giving theoretical knowledge to the class in order for the application phase of basic language skills. Considering speech skill in connection with the lesson, the practices may be carried into when students attend in the class instead of giving theoretical information about prepared speech required by this skill. Thus, the time is saved and the students are not bored in the class due to the theoretical knowledge given through simple expression. Discussions may be arranged and some more effective and productive applications can be done in order to develop verbal skills of the students.

Considering the writing skill, the situation is the same. Considering that the knowledge required to be given in the class about writing skills have been learnt by the student before, more effective and productive lessons can be taught in order for both writing and evaluation process at the class environment.

\subsection{A Recommendation about the Teaching of Ottoman Turkish Course with Reference to Flipped Classroom Learning Model}

\subsubsection{Preparation to the Lesson}

With reference to the flipped classroom learning model, the preparations required to be realized by the teacher and learners of the Ottoman Turkish Lesson have been dwelled on. The aim of Ottoman Turkish lesson is to make students gain the language skills and their processes. The preparation phase for Ottoman Turkish lesson should be application oriented. Teachers primarily should limit the subject that they are going to teach. They should clearly determine what, when and how long they teach. It increases the quality of lesson presentations to be prepared and affects the effectiveness on the presentations. It may be useful that the teachers start working by determining the platforms that they will share videos with their students. It may be social networks, e-mail or other platforms. They should prepare a video presentation about the lesson or use the presentations comply with the target of the lesson through the resources that are accord with the subject. The timing of these presentations should be arranged according to the students and subjects as long videos may affect students negatively. These videos should pertain to the theoretical part of the lesson. Students should have knowledge about the subject before attending to the class. The informative presentations to be submitted to the students should clearly explain the subject in general terms and contain various visual and audial stimulus. For instance, if alphabet is being taught, short information should be given concerning the historical development of Arabic letters and it is ensured that students should focus on the subject. Afterwards, the articulation about the pronunciation of these letters should be given. The writing of Arabic letters should be shown practically. Some examples should be indicated about the cursive and separate letters. The usage of real environments in videos may be more effective. The effectiveness of the videos may be enhanced by showing letters in colors, presenting important aspects in different color tones and preparing videos in the class using the board. The videos should be watched by those who prepared them or another expert of the field if possible from beginning till the end and the deficiencies should be removed if they exist. Thus the videos are put in the final form.

After preparing videos properly, it should be clarified about what students may learn from the videos. Relatedly, study papers should be prepared on an electronic platform. The short, clear and proper questions should be prepared for the parts before and after the video. Thanks to the questions before the video, the students shall have knowledge about the reason for watching those videos. Besides, the questions may provide high motivation to students before the video. Afterwards, they should answer the questions about the things they have learnt from the videos. Through these questions, the students may make self-evaluations about the things they learned and prove that they have watched those videos. It may help practitioner to have knowledge about the rating of the videos and may also have more comfortable practicing environment in the class.

Lesson presentations and study papers are uploaded to the determined platform with students after being reviewed once more. The students should be informed in advance about the time of uploading operation. The process works better if the practitioners follow up their students constantly and have a good command of knowledge about the platforms where the applications will be loaded.

The students are required to review the lesson presentations and study papers sent to them by practitioners before the lesson and have necessary information about them. Through this way, they will obtain the information about the next lesson. For instance, by means of the lesson presentation sent to the students about the next lesson, in which Arabic letters will be handled, the students will have knowledge about Arabic letters, observe how to pronounce these letters and how to write them practically and try to learn. Thus, the students will have chance to ask more questions, practice and work in groups during the lesson. In this way, they may have a positive attitude towards the lesson that they will have knowledge and it may affect the success of the lesson in a positive way. The preparations to be done by the teachers and students are indicated in the table below: 
Table 1. Pre-lesson preparations of teacher and students

\begin{tabular}{ll}
\hline Preparation of teacher & Preparations of student \\
\hline $\begin{array}{l}\text { Determination of the time of uploading and platforms where } \\
\text { teachers share the videos with the students. }\end{array}$ & $\begin{array}{l}\text { Determination of the time of uploading and platforms where the } \\
\text { students share the videos with teachers. } \\
\text { Fubject is determined. }\end{array}$ \\
$\begin{array}{l}\text { Follows up the lesson presentations and study papers before the } \\
\text { lesson. }\end{array}$ \\
$\begin{array}{l}\text { Presentations are prepared about the subject or suitable } \\
\text { presentations are determined. }\end{array}$ \\
$\begin{array}{l}\text { Pasentations are reviewed with the experts and they are } \\
\text { thanks to study papers. }\end{array}$ \\
$\begin{array}{l}\text { Has a positive attitude towards lesson as s/he is informed about } \\
\text { the subject. }\end{array}$ \\
$\begin{array}{l}\text { Questions are prepared for the parts before and after the lesson } \\
\text { presentations. }\end{array}$ \\
$\begin{array}{l}\text { Questions are reviewed again with the presentations with a high level of motivation. } \\
\text { Lesson presentations and study papers are uploaded to the } \\
\text { determined platform. } \\
\text { Students are monitored in the platform after uploading process. }\end{array}$ \\
\hline
\end{tabular}

\subsubsection{Teaching the Lesson}

With reference to the flipped classroom learning model, the teaching phase of Ottoman Turkish lesson should be handled after the preparations of teacher and learners for Ottoman Turkish lesson. After the preparations indicated in preparation phase, the students attend to the class with knowledge of the subject. Firstly, the teachers, in order to determine their knowledge, draw out the students about some questions specified in study papers. Furthermore, the teachers draw out students about the knowledge which is expected to be gained during the lesson presentations. The teacher verifies that all of them have watched lesson presentation. In the contrary case, the teacher takes measure by finding out the source of the problem.

The teachers pass to practice part after a brief introduction for the lesson. For instance, the teachers make students recognize the Arabic letters by calling them to the board. The practice of writing on the board and pronunciation are made by the teacher. Thus, the teacher passes to practice without showing the pronunciation of letters, giving theoretical information about letters and writing letters on the board. However, she/he sometimes has to realize those practices. All students are given an opportunity to practice and the attendance to the lesson is ensured. Visual and audial stimulus can be used as well. A practicing environment can be created to make students learn letters better through educational games.

A studying environment can be created with a group. The students are led to communicate with each other about the subject. For instance, each group represents certain letters and they make practice about their characteristics. Some groups are created such as the group of cursive letters or separate letters. Thus, the lessons become more entertaining and productive. Some difficult subjects may be learnt through in-group or intergroup activities. The deficiencies arising from individual differences may be overcome through this way. The students revise the subject in groups or individually or a general overview may be realized by the teacher at the end of the lesson. A discussion environment may be created about the subject.

The teachers should be a good observer during the teaching of the lesson and they should determine the failing parts of the lesson. The teacher should be a good guide during the lesson. She/he makes lesson workable with the students and tries to save enough time for the practicing. The students should be involved in all decisions that will be taken. The teachers should ask the opinion of students about the lesson presentations and study papers. Thus, the teachers both review the lesson and prepare next presentations more carefully. They inform students about the time of uploading of the presentations prepared for the next lesson and warn the students related to these presentations. The preparations to be done by the teachers and students during the teaching of the lesson are indicated in the table below:

Table 2. The preparations to be done by the teachers and students during the teaching of the lesson

\begin{tabular}{|c|c|}
\hline Teachers & Students \\
\hline Starts to the lesson with attention-grabbing words. & Be prepared for the lesson. \\
\hline $\begin{array}{l}\text { Draws out students about the lesson presentations and study } \\
\text { papers. }\end{array}$ & $\begin{array}{l}\text { Talks about the study papers and presentations that they have } \\
\text { watched. }\end{array}$ \\
\hline $\begin{array}{l}\text { Passes to practice related to the lesson. Uses visual and } \\
\text { audial stimulus. The letters are introduced through } \\
\text { educational games. }\end{array}$ & $\begin{array}{l}\text { Carries out the practices that should be done during the lesson. } \\
\text { Follows up visual and audial stimulus. Tries to recognize letters } \\
\text { through educational games. }\end{array}$ \\
\hline Creates the groups. & Determines th \\
\hline Ensures in-group and intergroup interactions. & Creates an interaction environment in-group and intergroup. \\
\hline Ensures the revision of subject in general sense. & Reviews the \\
\hline Gets criticism about lesson presentations. & Makes criticism about the lesson presentations. \\
\hline $\begin{array}{l}\text { Gets the opinions of students about the next lesson } \\
\text { presentation and determines the time for sharing these } \\
\text { presentations. }\end{array}$ & $\begin{array}{l}\text { Opines about the next presentations and be informed about the time } \\
\text { of sharing of these presentations for the next lesson. }\end{array}$ \\
\hline
\end{tabular}




\subsubsection{Evaluation of Lesson}

With reference to flipped classroom learning model, the following points may be indicated about the evaluation process of Ottoman Turkish Lesson: The students have required knowledge about the subject after the studies indicated during the teaching of the lesson and they realize adequate practice. Thus, an intergroup discussion environment is created related to the lesson. The teacher may lead in-group and intergroup students to ask questions to each other about the subject. Teachers may interfere to the process from time to time. The evaluation process may be realized through study papers. Following the lesson presentations, the questions on study papers may be asked again.

The evaluations may be realized by using audiovisual tools. For instance, students may both be asked to give information about those letters theoretically and make pronunciation and writing practices. With the reference to the short texts to be projected to the board, some questions may be asked about the letters and the usage of these letters. Following questions may be asked about the lesson and the practice at the end of the lesson: What have you learnt? Students may be asked to list the answer of this question. Where and how did you learn? By means of this question, the teacher has knowledge about the stakeholders and tools during the learning process. Students may also be asked to prepare questions about the subject and practice. Thus, the questions forgotten or ignored by the teacher may be determined.

\section{Conclusion and Recommendations}

It has been concluded that flipped classroom learning model is an applicable model for all learning skills. This model is applicable in each class level where language education is given if required infrastructure is created. As indicated above, another aspect obtained as a result of this study is that the teachers show their skills to make a good preparation and transform the classroom into an effective practicing environment for the students. It is concluded that the teachers and students should be informed about this model. It is also determined that the education planners, teachers and principals have required information about flipped classroom learning model and make an endeavor to provide material and environment for this model and consequently the education may be saved from being trapped inside four walls in information and communication era if these conditions are ensured.

In conclusion, the time out of class prepares learning individuals for the studies realized in the class through flipped classroom learning model. The teachers evaluate these out-of-class learning's and preparations. Students learn in an effective and productive way without remaining passive in the classroom environment thanks to this model. Most of the time offers opportunity for an active education inside the classroom in company with a teacher rather than a theoretical information education in flipped classroom learning model. According to these features of flipped classroom learning model, it can be said that this model is effective, productive and practicable compared to the traditional education method. Thus, it shows that the examined model is practicable in Turkish educational field.

The student can reach to required information when needed by receiving education in an active platform if flipped classroom learning model is used with the models such as digital learning model. When considering the pedagogic features of the student, it privatizes the education, makes education productive and allows effective teaching for student in flipped classroom learning model and digital platforms (Gençer, Gürbulak and Adıgüzel, 2014; Seamen \& Gaines, 2013; McGivney \& Xue, 2013; Talbert, 2012; Toto and Nguyen, 2009). The teacher, in flipped classroom learning model, is no longer a teacher who transmits the information in the class through different technological devices. Teacher may present learning platforms to students at different times through individual and group studies. It is concluded that the teacher may realize more productive studies concerning the subjects that are not comprehended by the students (Serçemeli, 2015; Hamdanvd, 2013). This model allows more comfortable education ambiance for the teacher and students. It also allows more effective and productive education process for all stakeholders of the education. Thus, it is concluded that the students, who are supposed to be active in language skill teaching, learn language skills better thanks to this model.

The recommendations about the availability of flipped classroom learning model in Turkish education are listed below:

1. Firstly, the teachers should have required knowledge about the flipped classroom learning model.

2. The equipment to be used both by the teachers and students should be supplied for this model and required background should be prepared for their usage.

3. The teachers should prepare lesson presentations in an effective and qualified way.

4. The studies should be realized about the usage of flipped classroom learning model in Turkish education and Ottoman Turkish lesson in private besides practical studies in related universities.

5. Special units should be created concerning the application of this model within the body of universities. 


\section{References}

Bayhan, P., Olgun, P., \& Yelland, N. J. (2002). A study of pre-school teachers' thoughts about computer-assisted instruction. Contemporary Issues in Early Childhood, 3(2), 298-303. http://dx.doi.org/10.2304/ciec.2002.3.2.11

Bergmann, J., \& Sams, A. (2012). Flip your classroom: Reach every student in every class every day. Alexandria, VA: International Society for Technology in Education.

Boyraz, S. (2014). Ingilizce öğretiminde tersine ĕgitim uygulamasının değerlendirilmesi. Yayımlanmamış Yüksek Lisans Tezi, Sosyal Bilimler Enstitüsü, Afyon Kocatepe Üniversitesi. Afyon.

Davies, R. S., Dean, D. L., \& Ball, N. (2013). Flipping the classroom and instructional technology integration in a college-level information systems spreadsheet course. Educational Technology Research and Development, 61(4), 563-580. http://dx.doi.org/10.1007/s11423-013-9305-6

Davis, B. C., \& Shade, D. D. (1994). Integrate, don't isolate! Computers in the early childhood curriculum. ERIC Digest December, 1994. No. EDO-PS-94-17.

Demiralay, R. (2014). Evde ders okulda ödev modelinin benimsenmesi sürecinin yeniliğin yayılımı kuramı çerçevesind eincelenmesi. Yayımlanmamış Doktora Tezi Eğitim Bilimleri EnstitüsüGazi Üniversitesi. Ankara.

Demiralay, R., \& Karataş, S. (2014). Evde ders okulda ödev modeli. Eğitim ve Öğretim Araştırmaları Dergisi, 3(3), 333-340.

Fautch, J. M. (2015). The flipped classroom for teaching organic chemistry in small classes: is it effective? Chemistry Education Research and Practice, 16, 179-186. http://dx.doi.org/10.1039/C4RP00230J

Findlay-Thompson, S., Saint, M., \& Mombourquette, P. (2013). Evaluation of a flipped classroom in an undergraduate business course. Business Education, Accreditation, 8(2), 63-70.

Gannod, G., Burge, J., \& Helmick, M. (2008). Using the inverted classroom to teach software engineering. international conference on software engineering (ICSE). Leipzig, Germany, 10-18 May 2008. http://dx.doi.org/10.1145/1368088.1368198

Gençer, B. G. (2015). Okullarda ters-yüz sınıf modelinin uygulanmasına yönelik birvaka çalışması. yayımlanmamış Yüksek Lisans Tezi, Eğitim Bilimleri Enstitüsü Bahçeşehir Üniversitesi. İstanbul.

Gençer, B. G., Gurbulak, N., \& Adiguzel, T. (2014). A new approach in learning and teaching: The Flipped Classroom. In A.C. Ilhan, A. Isman, C. Birol\& A. Eskicumali (Eds.), Proceedings of International Teacher Education Conference (pp. 881-888).

Hamdan, N., McKnight, P., McKnight, K., \& Arfstorm, K. M. (2013). A review of flipped learning. Flipped Learning Network. Retrieved November 2,

http://researchnetwork.pearson.com/wpcontent/uploads/ExecSummaryFlippedLearnig.pdfadresinde 20.04.2016tarihinde alınmıştır

Johnson, L. W., \& Renner, J. D. (2012). Effects of the flipped classroom model on a secondary computer applications course: student and teacher perceptions, questions and student achievement. Unpublished Phd thesis, University of Louisville.

Kapçık, A. C. (2014). Fipped classroom eğitim modelinin ortaokul öğrencileri üzerindeki etkilerinin değerlendirilmesi. TUBITAK 45. Ortaöğretim Öğrencileri Araştırma Projeleri Yarışması. İstanbul.

Love, B., Hodge, A., Grandgenett, N., \& Swift, A. W. (2014). Student learning and perceptions in a flipped linear algebra course. International Journal of Mathematical Education in Science and Technology, 45(3), 317-324. http://dx.doi.org/10.1080/0020739X.2013.822582

Mason, G. S., Shuman, T. R., \& Cook, K. E. (2013). Comparing the effectiveness of an inverted classroom to a traditional classroom in an upper-division engineering course. IEEE Transactions on Education, 56(4), 430-435. http://dx.doi.org/10.1109/TE.2013.2249066

Mattis, K. V. (2014). Flipped Classroom Versus Traditional Textbook Instruction: Assessing Accuracy and Mental Effort at Different Levels of Mathematical Complexity.Technology, Knowledge and Learning, 1-18.

McGivney-Burelle, J., \& Xue, F. (2013). Flipping calculus. PRIMUS: Problems, Resources, and Issues in Mathematics Undergraduate Studies, 23(5), 447-486. http://dx.doi.org/10.1080/10511970.2012.757571

Missildine, K., Fountain, R., Summers, L., \& Gosselin, K. (2013). Flipping the classroom to improve student performance and satisfaction. Journal of Nursing Education, 52, 597-599.

http://dx.doi.org/10.3928/01484834-20130919-03 
Odabaş1, F., \& Namlu, A. G. (2008). Türkçe Öğretiminde Ortamlar. http://www.anadolu.edu.tr/aos/kitap/IOLTP/2277/unite07.pdf.adresinden 14.04.2016tarihindealınmıştır

Odabaşı, H. F. (2010). Bilgi ve iletişim teknolojileri ışı̆̆ında dönüşümler. Ankara: Nobel Yayınları.

Prensky, M. (2001). Digital natives, digital immigrants. On the Horizon, 9(5), 1-6. http://dx.doi.org/10.1108/10748120110424816

Roach, T. (2014). Student perceptions toward flipped learning. New methods to increase interaction and active earning in economics. International Review of Economics Education, 17, 74-84. http://dx.doi.org/10.1016/j.iree.2014.08.003

Seaman, G., \& Gaines, N. (2013). Leveraging digital learning systems to flip classroom instruction. Journel of Modern Teacher Quarterly, 1, 25-27.

Serçemeli, M. (2015).Muhasebe eğitiminde yeni bir yaklaşım önerisi: tersyüz edilmişsınıflar. Muhasebe ve Finansman Dergisi, Ocak, 115-126.

Sever, G. (2014). Bireysel çalgı keman derslerinde çevrilmiş öğrenme modelinin uygulanması. Eğitimde Nitel Araştırmalar Dergisi, 2(2), 27-42.

Spector, J. M. (2013). Emerging educational technologies and research directions. Educational Technology \& Society, $16(2), 21-30$.

Strayer, J. F. (2012). How learning in an inverted classroom in fluences cooperation, innovation and task orientation. Learning Environments Research, 15(2), 171-193. http://dx.doi.org/10.1007/s10984-012-9108-4

Talbert, Robert (2012). Inverted Classroom, Colleagues: 9:1, Article 7. http://scholarworks.gvsu.edu/colleagues/vol9/iss1/7adresinden 20.04.2016 tarihinde alınmıştır

Temizyürek, F., \& Ünlü, N. A. (2015). Flipped Classroom. Bartın Üniversitesi Eğitim Fakültesi Dergisi 4(1), 64-72. http://dx.doi.org/10.14686/BUEFAD.2015111015

Tezci, E., \& Perkmen, S. (2013). Oluşturmacı perspektiften teknolojinin öğrenme-öğretme sürecine entegrasyonu. Çă̆ıltay, K. ve Göktaş, Y. (Ed.). Öğretim teknolojilerinin temelleri: Teoriler, araştırmalar, eğilimler (s.185-211). Ankara: PEGEM

Torun, F., \& Dargut, T. (2015). Mobil öğrenme ortamlarında ters yüz sınıf modelinin gerçekleştirilebilirliği üzerine bir öneri. Adnan Menderes Üniversitesi Ĕ̈itim Fakültesi Eğitim Bilimleri Dergisi, 6(2), 20-29.

Toto, R., \& Nguyen, H. (2009). Flipping the work design in an industrial engineering course. ASEE/IEEE Frontiers in Education Conference. San Antonio, TX. http://dx.doi.org/10.1109/fie.2009.5350529

Touchton, M. (2015). Flipping the classroom and student performance in advanced statistics: Evidence from a quasi-experiment. Journal of Political Science Education, 11(1), 28-44. http://dx.doi.org/10.1080/15512169.2014.985105

Tucker, B. (2012). The Flipped Classroom. Retrieved from http://educationnext.org/the-flipped-classroom/adresinden14.04.2016 tarihinde alınmıştır

Tune, J. D., Sturek, M., \& Basile, D. P. (2013). Flipped classroom model improves graduate student performance in cardiovascular, respiratory, and renal physiology. Advan. in Physiol. Edu., 37(4), 316-320. $\mathrm{http}: / / \mathrm{dx}$.doi.org/10.1152/advan.00091.2013

Turan, Z. (2015). Ters yüz sinıf yönteminin değerlendirilmesi ve akademik başarı, bilişsel yük ve motivasyona etkisinin incelenmesi. Yayımlanmamış DoktoraTezi. Atatürk Üniversitesi EğitimBilimleri Enstitüsü. Erzurum.

Turan, Z., \& Göktaş, Y. (2015). Yüksek öğretimde yeni bir yaklaşım: Öğrencilerin tersyüz sınıf yöntemine ilişkin görüşleri. Yüksek ögretim ve Bilim Dergisi, 5(2), 156-164.

Verleger, M. A., \& Bishop, L. J. (2013). The flipped classrom: A survey of the research. 120th ASEE Conference \& Exposition. American Society for Engineering Education, 20-26.

Zownorega, J. S. (2013). Effectiveness of flipping the classroom in a honors level, mechanics-based physics class. Master's Thesis. Eastern Illinois University.

\section{$(\mathrm{cc}) \mathbf{E Y}$}

This work is licensed under a Creative Commons Attribution 3.0 License. 